\title{
Improvement of Human Resources Quality through Vocational Training in Tourism in Karimunjawa Islands (Central Java, Indonesia): A Pro-Economical Tourism Approach
}

\author{
S. Eko Putro ${ }^{1}$, Sukirno ${ }^{1}$, Budi S. ${ }^{1} \&$ Didik W. ${ }^{1}$ \\ ${ }^{1}$ Muhammadiyah Purworejo University, Indonesia \\ Correspondence: S. Eko Putro, Muhammadiyah Purworejo University, Indonesia. E-mail: putrowid@yahoo.co.id
}

Received: January 6, 2016

Accepted: February 28, $2016 \quad$ Online Published: July 26, 2016

doi:10.5539/ies.v9n8p28

URL: http://dx.doi.org/10.5539/ies.v9n8p28

\begin{abstract}
The effort to improve human resource quality is not easy to be implemented. This effort becomes more complicated to do when implemented to the group of poor community, especially in this case marginal community of small island. This research analyzes the characteristic of poor household in small island as well as the strategy of poverty eradication through the improvement of human resource quality. This is a qualitative research supported by quantitative approach. Data was collected through in-depth interview, focus group discussion, and survey. Research result indicates that the groups of traditional farmers and fishermen spread out of Karimunjawa islands who are categorized extremely poor and having limited human resource. In one side, Karimunjawa apparently has a potential to be a tourist spot. Karimunjawa inhabitants are interested to take part in economical tourism activity. This study recommends a strategy to eradicate poverty and improve human resource quality through Pro-Poor Tourism (PPT) Approach which is based on vocational tourism training.
\end{abstract}

Keywords: poverty, human resource, small island, vocational training, tourism, pro-economical tourism approach

\section{Introduction}

\subsection{Background}

As an archipelago country with the $70 \%$ sea zone, Indonesia which has more than 17.508 islands faces a problem in terms of improvement and development in small island areas. One of the main problems faced by the small islands inhabitants is poverty. Poverty in small islands becomes main issue to Indonesia as a maritime country. Most of small islands inhabitants' livelihoods depend on sea sector (fishermen) and agricultural sector (farmers). Fishermen and farmers are two sectors where poverty has a big number (Stanford et al., 2013; Rashed et al., 2011; Dien, 2009). Typical character of small island causes farmers in small islands facing plurarized in their production process. Limitation of land, limited water availability, limited market access, and the threat of climate change cause the community of farmers becomes a community of small island who is difficult to develop. Being a fisherman becomes a significant and important job choice for income improvement and food security to poor households with bad agricultural land (Martin et al., 2013). In the other hand, farmers are under the rise of threat of climate and environmental change, such as the rise of sea temperature, sea acidity, and the rise of sea water surface (Cochrane et al., 2009; Johnson \& Welch, 2010). One of small island areas in Indonesia is Karimunjawa islands.

Karimunjawa archipelago consists of small islands groups with the number of approximately 27 small islands. This archipelago is administratively included in 1 sub-regency (sub-district) namely Karimunjawa sub-regency, Jepara Regency, Cenral Java Province. Karimunjawa island becomes the center of the sub-regency which is located $\pm 83 \mathrm{~km}$ from Jepara. This is an area of approximately $110.117,3$ hectares, with air temperature of $23^{\circ} \mathrm{C}-32^{\circ} \mathrm{C}$, altitude of $0-605$ meters from the bottom of the sea with the geographical location of $5^{\circ} 42^{\prime}-6^{\circ} 00^{\prime}$ South Latitude, and $110^{\circ} 07^{\prime}-110^{\circ} 37^{\prime}$ East Long (Ministry of Forestry, 2008). The number of pre-welfare (extremely poor) families and welfare 1 (poor) families in Karimunjawa reaches the number of 1.803 households or $61.2 \%$ from the total families in Karimunjawa archipelago. 


\subsection{Rationale for the Topic}

Research on transformation strategy of livelihood is not yet specifically many conducted in Karimunjawa. Therefore, this research is important to do as an effort to provide alternative of empowerment strategy of human resource and poverty eradication in small islands with their various local potentials. Specifically, there are two objectives of this research, including 1) analyzing the characteristic and human resource quality of poor household in Karimunjawa archipelago; 2) developing a local potential which based on strategy of human resource empowerment in small islands.

\section{Method}

The current study employed a survey method. This involved a large number of population, randomly sampled out - to be exact, stratified random sampling with the following profiles of the research subjects.

Table 1. Research subject profiles by job occupation

\begin{tabular}{llcc}
\hline No & Occupation & $\sum$ & $\%$ \\
\hline 1 & Professional (doctors, engineers, lawyers) & 77 & 19.25 \\
2 & Business person & 120 & 30.00 \\
3 & Officers (army, police) & 86 & 21.50 \\
4 & Education (teachers, educational staff) & 78 & 19.50 \\
5 & Housewives (women without formal employment) & 39 & 9.75 \\
& Total & 400 & 100.00 \\
\hline
\end{tabular}

\subsection{Data Collection and Analysis}

The research instrument was printed like a booklet. There were approximately 500 exemplars distributed throughtout the area of Karimunjawa Island. Table 1 above was made on the basis of the returned survey booklets completely filled out. The variables under the survey include characteristics of poverty level on the basis of which poverty eradication could be formulated. In-depth interviews with selected individuals and Focus Group Discussion (FGD) were also held to strengthen the findings.

Returned survey booklets were analyzed in order to come up with the classification (\%) of the poverty levels in each area in question. Certain individuals were contacted for in-depth interviews and FGD.

\section{Results}

\subsection{Characteristics of Household Poverty in Karimunjawa Islands}

Understanding the characteristic of poor household is a precise starting point in designing policy and program to improve their welfare. According to Ahmed et al. (2007), the poorest household is defined as $20 \%$ below average income of household which it's members live with less than US \$ $0.50 /$ day. Our focus is the characteristic of poorest household (pre-welfare) that will be observed based on various aspects starting from relationship between food policy and consumption behaviour of household, including the pattern of food consumption outcome, geographical aspect, to social condition. Poorest households are often found in relatively remote locations where access to public infrastructures and facilities such as streets and markets is limited. This brings problems to them because the variety of food is limited and the price becomes expensive. Poverty based on the heavy geographical condition also blocks the access to the other basic needs, such as health treatment and education. In terms of human and social resources, members of poorest households tend to be educated and most possibly expelled from a certain opportunity systemically.

\subsection{The profiles of Poverty at the Sub-Regency of Karimunjawa Islands}

The profile of poverty at the sub-regency of Karimunjawa Island, Central Java Indonesia can be seen in Table 2 below: 
Table 2. The profile of poverty at the sub-regency of Karimunjawa Island, Central Java Indonesia

\begin{tabular}{ccccccc}
\hline Village & Pre-Welfare & Welfare 1 & Welfare 2 & Welfare 3 & Welfare Plus & Total \\
\hline Karimunjawa & 481 & 400 & 251 & 218 & 156 & 1.506 \\
Kemujon & 271 & 309 & 197 & 105 & 53 & 935 \\
Parang & 125 & 102 & 48 & 27 & 23 & 325 \\
Nyamuk & 125 & 102 & 48 & 27 & 23 & 325 \\
Total & 937 & 866 & 528 & 367 & 245 & 2.943 \\
\hline
\end{tabular}

Source: Karimunjawa Regency in Number; Central Statistic Bureau, 2014.

From Table 2, it is clear that Karimunjawa sub-regency administratively has 4 villages, namely Karimunjawa, Kemujon, Parang dan Nyamuk. All of the villages in Karimunjawa regency has a typhology of beach or coastal area with the altitude of below 500 meters from the bottom of the sea.The center of Karimunjawa sub-regency, Karimunjawa island, is located 40 miles from Kartini Jepara harbor, and can be achieved by using Ekspres Bahari ship with the duration of approximately 2 hours, meanwhile by using a regular fast ship, the duration becomes approximately 4 hours.

In 2013, the population of Karimunjawa island reached 9.016 people consisting 4.547 men inhabitants and 4.469 woman inhabitants. This is sub-regency with the smallest number of inhabitants in Jepara Regency (0.78\%), divided into 2.621 households, therefore in average, each household in Karimunjawa sub-regency consists of 3-4 people. The biggest number of inhabitants is in Karimunjawa village. Consisting 4.557 people or $50.54 \%$ of total population of regency inhabitants. Meanwhile, The smallest number of inhabitants is in Nyamuk village. Consisting 551 people or $6.11 \%$ of total population of regency inhabitants.

Fulfillment of food necessity in Karimunjawa Sub-Regency in 2013, mostly comes from outside Karimunjawa Regency itself. Despite an area of of cultivation of $18 \mathrm{Ha}$, the volume of rice harvest is only $10 \mathrm{Ha}$ with the production of 55 Tons. The other food plantations, such as cassava, has a harvest volume of $4 \mathrm{Ha}$ with the production of 150 tons, meanwhile corn has a harvest volume of $2 \mathrm{Ha}$ with the production of 11 tons. The main potential of Karimunjawa Sub-Regency is local community based plantation, such as: clove, coconut, kapok, and cashew. Sub sector of husbandry/ranch is divided into big scale husbandry, small scaled husbandry, and poultry husbandry. Big scale husbandry in Karimunjawa includes local cow, goat, meanwhile the most dominant poultry is free-range chicken.

Besides the potential of sea commodity, Karimunjawa Sub-Regency has 130 business units of sea weed cultivation, with the amount of production of $15,393,030 \mathrm{~kg}$ or 15.39 tons and production value of $\mathrm{Rp}$ $13,562,328,000$. This is the only Sub-Regency producing sea weeds in Jepara Regency. In spite of the declining value of sea weed cultivation in throughout 2014, one of the economics potentials namely tourism sector, in fact increased. Karimunjawa archipelago has a very big tourism potentials to be developed, such as marine tourism (diving, fishing, swimming, and many more), beach/coastal tourism (white sands), sea garden tourism (very beautiful coral reef), and religious tourism (tomb of Sunan Nyamplungan). The number of tourist visit, both domestic and foreign tourists increases every year. The potential of Karimunjawa archipelago as a favorite destination to the foreign tourists is more exposed when the visit of of foreign tourists continues to increase. In 2014, there were 8.699 foreign tourists visiting Karimunjawa. This is an increasing when compared with the previous years. 2012 with the number of only 5.005 visitors, and 2013 with the number of only 5.372 visitors

The emerging problem, according to the Central Statistic Bureau of Jepara Regency in 2014 is the poverty level which is considered high, as much as $60.2 \%$ of poor households. These poor households are spread out in 4 villages, with the biggest percentage in Karimunjawa village and Kemujen village (Table 1). The number of poor and extremely poor households in Karimunjawa sub-regency reaches 1.803 households with the total population of 7.212 people (with the assumption of 4 people within 1 household).

The number of high poverty in Karimunjawa sub-regency is parallel to the very low educational level. Most of inhabitants of Karimunjawa graduated only from Elementary School or same level (47.98\%), and 32.67\% did not even graduate from Elementary School (ever attended but did not graduate). With the big group of productive ages, the quality of human resource in Karimunjawa sub-regency is considered low.

Most of inhabitants of Karimunjawa regency (88.56\%) work in informal sector, with biggest percentage (59.93\%) of them are fishermen and $19.32 \%$ of them are farmers. Meanwhile, the other informal sectors that become the 
livelihood of Karimunjawa inhabitants are farm workers, craftsmen, traders, cattlemen, and mechanics. The livelihoods in tourism sector is increasingly interesting to inhabitants of Karimunjawa, as a result, many of them switch job or find another side job. The economic activities of tourism which are run by several inhabitants of Karimunjawa include making of souvenirs, providing of boat rental, guiding of tourists, providing simple homestay. The economic activities of tourism who are run by them has not yet become the main activity. They only run temporarily, depend on the level of crowds of tourist visit and the climate condition in Karimunjawa.

\subsection{Characteristics of Income-Based Levels of Poverty}

On the basis of income, the poverty at the areas in question can be seen from Table 3 below:

Tabel 3. Income of Family Heads in Karimunjawa Regency

\begin{tabular}{|c|c|c|c|c|c|c|c|}
\hline \multirow{3}{*}{ No } & \multirow{3}{*}{$\begin{array}{l}\text { Family Income } \\
\text { (IDR) }\end{array}$} & \multicolumn{4}{|c|}{ Village } & \multicolumn{2}{|c|}{ Amount } \\
\hline & & \multicolumn{2}{|c|}{ Karimunjawa } & \multicolumn{2}{|c|}{ Kemujon } & \multirow[b]{2}{*}{ Total } & \multirow[b]{2}{*}{$\%$} \\
\hline & & $\begin{array}{c}\text { 17-30 Years } \\
\text { Old }\end{array}$ & $\begin{array}{c}>30 \text { Years } \\
\text { Old }\end{array}$ & $\begin{array}{c}\text { 17-30 Years } \\
\text { Old }\end{array}$ & $\begin{array}{c}>30 \text { Years } \\
\text { Old }\end{array}$ & & \\
\hline 1 & $<500.000$ & 15 & 10 & 8 & 4 & 37 & $61.7 \%$ \\
\hline 2 & $500.000-1.000 .000$ & 5 & 10 & 2 & 6 & 23 & $38.3 \%$ \\
\hline 3 & $>1.000 .000$ & 0 & 0 & 0 & 0 & 0 & 0 \\
\hline
\end{tabular}

Source: Field data, 2015.

Table 3 above shows that Poverty indicator of farmers and fishermen is able to be observed based on income and expenditure of household. By adopting poverty line, according to Sajogyo (1978) in rural area is equal to $320 \mathrm{~kg}$ of hulled rice per capita per year, or $1.600 \mathrm{~kg}$ per household per year. With this measurement, then the poverty line of household in rural area is 1,150,000 per household per month (with the assumption of hulled rice price of approximately Rp. 8,500/kg). Even though their income is below poverty line, farmers and fishermen in Karimunjawa sub-regency rarely experience hunger cases because they get sufficient carbohydrate supply around the island. Jaring Pengaman Posial (Government Aids Program to Poor Citizens) also supports their need of stapple food. Despite the fact that in certain seasons such as "musim baratan" (in the period of January-March) and "musim ombak besar" (big wave season), the need of food increases, and so does the price of the main food supplies in the market.

Field data of this research indicates that the group of extremely poor family is included in the group of productive household leader of 17-30 years old. This is of course relates with the quality of human resource which is still very low, resulting difficult to them to access economical resource. This group also has a typical characteristic of getting married in a relatively young age, both men and women. In terms of the number of family members, most of them have no more than 4 members.

\subsection{Characteristics of Poverty Based on Family Consumption Patterns}

The consumption pattern of household is considered as a most reliable indicator to economic development and citizen welfare of a country. For example, the increasing of income of households tends to increase their diet diversification and also increase the consumption of food with the higher nutrient values. Based on survey result of Kehidupan Keluarga Indonesia (Indonesian Family Life Survey), 1 household which is categorized poorest spent more than half of their budget on food (63\%) in 1997, and this number slightly decreased in 2007 to $61 \%$, this indicates that the income of household which is categorized poorest was spent on food ingredients. 


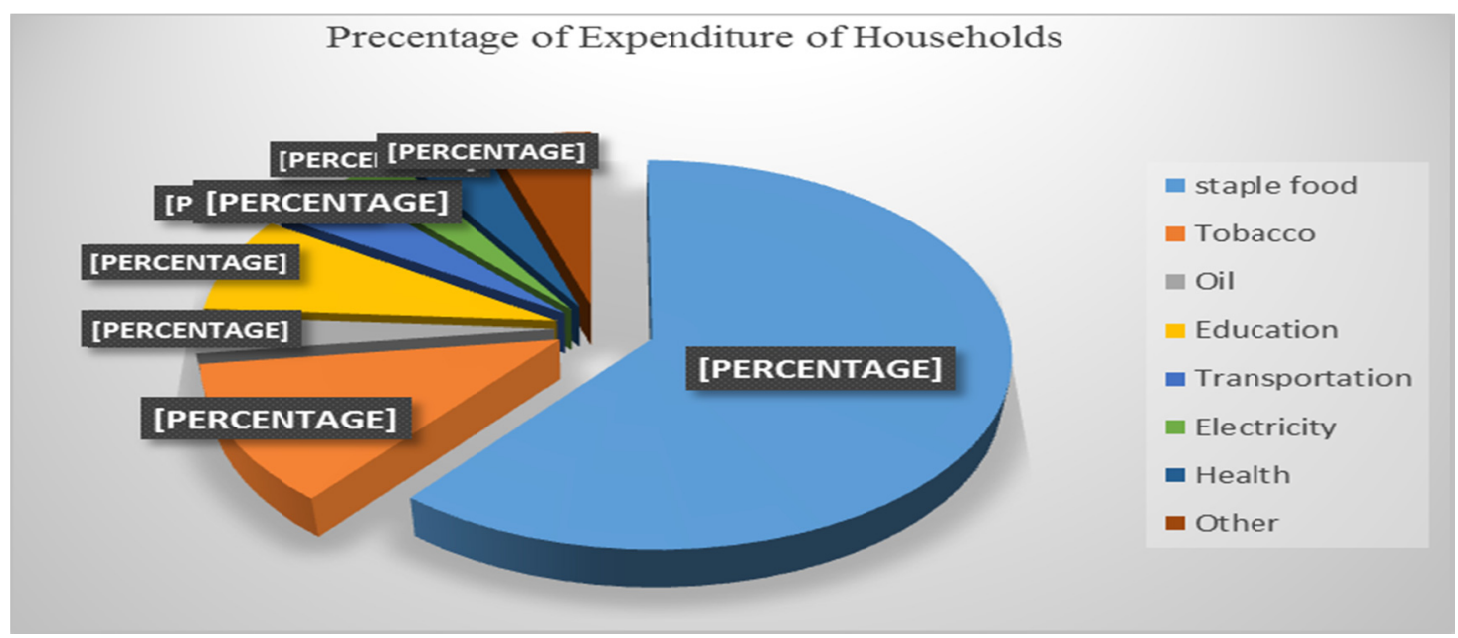

Figure 1. Percentage of family expenditure

This research result (Figure 1) also shows that most of respondents in Karimunjawa spent their income on food ingredients (61\%). In terms of food expenditure, the category of "staple food" dominates the outcome of budget of poorest households. Cigarette is the second biggest expenditure $(12 \%)$ in the group of poor households, particularly for the leader of poor households.

\subsection{Characteristics of Human Resources Quality}

The quality of human resource can be specifically described based on the level of education of inhabitants. The composition of inhabitants based on graduation of education provides an image of human resource quality. The need of highly educated employees is considered very important to the interest of development. This relates to competitiveness of human resource among various areas in facing the era of global competition in the future.

The inhabitants of Karimunjawa sub-regency aged 10 years old above who graduated (highest education) from Universities and Academies were 114 people (1.7\%), Senior High School or the same level 401 people (6\%), Junior High School or the same level 772 people (11.6\%), and Elementary School 2668 people (40\%). Meanwhile, the percentage of inhabitants of Karimunjawa sub-regency aged 10 years old above who did not graduate from Elementary School reaches 2715 people (40.7\%) (Composed based on data from BPS (Central Statistic Bureau).

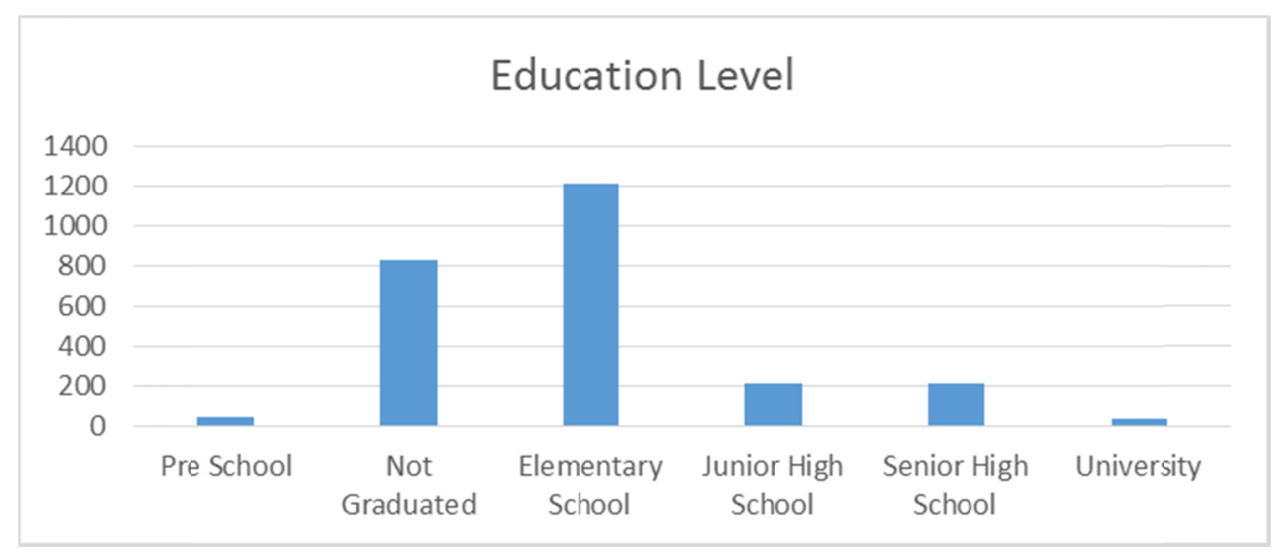

Figure 2. Educational level of Karimunjawa inhabitants

Based on fact that most of inhabitants graduated from Elementary School and some of them did not graduate from Elementary School, then the development of human resource in education sector in Karimunjawa sub-regency can be considered not yet going well, because most of the inhabitants graduated only from Elementary School and some of them did not even graduate. It means that the average duration of attending 
school in Karimunjawa archipelago reaches only 5.8 years. In one side, the literacy level in Karimunjawa archipelago is considered low. In 2014, the literacy level of inhabitants of Karimunjawa sub-regency aged 15 years old above reached $81 \%$. In other words, as much as $19 \%$ of inhabitants aged 15 years old above in Karimunjawa sub-regency are not or are not yet able to read and write.

The low human resource quality will cause the competitiveness of local human resource to be dominated by outside human resource in facing the era of global competition in the future. With the low or weak educational qualification of the inhabitants, a non-formal educational model in Karimunjawa sub-regency is required to face that competition, especially in terms of local potention of Karimunjawa. The inhabitants who have sufficient education and life skills will gain the opportunity to participate in the improvement and development of the area.

\subsection{Pro-Poor Tourism Approach to Improving Human Resources Quality in Karimunjawa Islands}

\subsubsection{PPT Approach to Empowerment of Local Inhabitants}

Pro-Poor Tourism (PPT) was introduced in 1999 and implemented in England for the goal of international development by exploring tourism as a contribution to reduce poverty (Ashley et al., 2001). The strategy of PPT development includes 1) improving economic benefits; to improve business opportunity to poor people, to improve work opportunities to poor people, to improve collective income of the community (payment) and 2) improving non-economic benefits, developing skill, training, operation, reducing environmental impact from tourism activities on poor people, solving social and cultural impacts from tourism activities. PPT approach is very interesting in the analysis of livelihood (Ashley, 2000; Ashley, Roe, \& Goodwin 2001). Analysis of livelihood is important if Tourism will be used as a contribution to the welfare of poor people in terms of economics or income. To maximize the contribution of household as well as to avoid the dependence of poor household, then tourism can be used as diversification of livelihood.

In the context of Tourism development, local participation is not only important to the workforce in this sector and the complementary industries, but also serves to support tourism visit through attitudes and culture in Tourism as the further step. The development of culture does not only depend on natural resource and scaled promotional appeals, but also the willingness of the local community to accept tourists and make sure that they have meaningful visit. The readiness of local community is a moral support for tourism sector and directly reflects their willingness to participate in this industry.

3.6.2 Vocational Training in Tourism as the Strategy of Human Resource Empowerment and Poverty Eradication

This research was conducted in the community of poor people in Karimunjawa archipelago. 10 heads of poor household were taken into in-depth interview to retrieve information about their willingness to reduce poverty in their community through the Tourism activities. Research result indicates that poor households are willing to take part in Tourism activities if those tourism activities (1) provide opportunity to work, (2) earn income, (3) build houses or shelter, (4) gain pride, (5) keep health, and (6) get the contribution of additional income for them.

An effort to eradicate poverty in Karimunjawa archipelago which is implemented through the improvement of human resource quality is the model of community empowerment. It is a vocational training oriented to the development of informal economical sector, particularly tourism sector. This model is selected because tourism sector is a current growing sector in Karimunjawa, and the inhabitants respond with their additional activities in that sector.

The development of education and vocational training in tourism which is improved in Karimunjawa consider 5 aspects including, (1) education and vocational training in tourism must be able to fulfill the work opportunity in tourism sector; (2) education and vocational training in tourism must be able to provide an effective access for the group of productive aged inhabitants to labor market as well as enter them into the productive economic of tourism. (3) education and vocational training in tourism must cover all of related parties, as an effort to build the connection among education and vocational training, the demand of the labor market, and business environment of tourism sector in Karimunjawa. (4) mechanism of education and vocational training must be sustainably designed in accordance with the situation, commitment, and the responsibility of stakeholder; (5) education and vocational training in tourism must be a part of sustainable development strategy in regional, national, and international levels.

The most important goal of education and training to improve human resource and eradicate poverty is empowerment of poor inhabitants not only with the basic knowledge, skill, but also the commitment of modern "ideology" to gain support and spiritual motivation to fight poverty. 


\section{Conclusion}

Poverty in Karimunjawa archipelago is categorized as income poverty, it is caused by the inability of inhabitants in managing and maximizing the potentials of local resources. Poverty in Karimunjawa archipelago can be observed based on the pattern of consumption of households.

The other causal factors of poverty are inter-connected each other, such as the low level of quality and the number of cultivated field, limited financial resource, the low level of technology access, and the most importantly the low level of human resource quality.

The strategy of poverty eradication in the area of Karimunjawa archipelago must be integrated, comprehensive, and sustainable. A strategy that can be implemented is the empowerment of human resource in Karimunjawa archipelago through vocational training in tourism with Pro Poor Tourism (PPT) approach. The government through the ministry of national education and local governments should organize vocational education and training in the areas of small islands. The Government will facilitate the vocational education institutions. This vocational training can be institutionalized in Community Learning Center. One of important parts in the strategy of empowerment of poor people is that the program does not only provide improvement of basic knowledge, skill, but also the commitment of modern"ideology" in gaining support and spiritual motivation to fight the poverty.

Pro-Poor Tourism (PPT) approach would not be successful if the implementation only performed by local people. They do not have human resources who has sufficient knowledge and ideas in terms of planning and implementation of local tourism program. First step to be taken in implementing Pro Poor Tourism (PPT) approach is providing them the knowledge and skill in managing local tourism program through education and tourism vocational. In this case, the community also needs support from the government. Ministry of Education or Local Agency of Education, particularly division of non formal Education are suggested to provide qualified mentors, provide tutorial, and make sure that local community is able to achieve success in tourism industry.

\section{Recommendation}

The government should be able to provide education and tourism vocational for poor households in the areas of small islands. Educational vocational facilities should be provided by the government and provide remuneration for all parties involved. For the implementation of the program requires regular evaluations programmed to determine the strength and weaknesses of the program. Non-governmental organizations, the company through its CSR program to be involved in funding and overseeing the program. Poor people who are trained to be facilitated to work independently or work in a company that is in the field of tourism, especially small island.

\section{References}

Alcock, P. (1997). Understanding Poverty. Macmillan Press. London. http://dx.doi.org/10.1007/978-1-349-25666-2

Arifin, B. (2007). Diagnosa Ekonomi Politik Pangan dan Pertanian. PT Raja Grafindo Persada, Jakarta.

Ashley, C. (2000). The Impacts of Tourism on Rural Livelihood's: Namibia's Experience. ODI, Working Paper 128 , London

Ashley, C., Roe, D., \& Goodwin, H. (2001). Pro Poor Tourism Strategies: Making Tourism Work for the Poor. PPT1, Pro-Poor Tourism/ODI, London

Berkes F., Mahon, R., McConney, P., Pollnac, R., \& Pomeroy, R. (2001). Managing Small-Scale Fisheries: Alternative Directions and Methods. IDRC, Ottawa.

Departemen Kehutanan. (2008). Statistik Balai Taman Nasional Karimunjawa. Dirjen Perlindungan Hutan dan Konservasi Alam, Semarang.

Dien, V. V. (2009). Poverty measurement, an application for small-scale fisheries in Bich Dam Island, Vietnam (Master thesis, University of Tromso, Norway \& Nha Trang University, Vietnam).

Ikiara, M. M., \& Odink, J. G. (2000). Fishermen Resistance to Exit Fisheries. Marine Resource Economics, 14, 199-213. http://dx.doi.org/10.1086/mre.14.3.42629265

Rashed-Un-Nabi, M., Hoque, M. A., Rahman, R. A., Mustafa, S., \& Kader, M. (2011). Poverty profiling of the estuarine set Bag Net fishermen community in Bangladesh. Res. World Econ., 2(2), 2e20.

Rijanta, R. (2005). Insularitas dan Keterbelakangan Ekonomi Wilayah menuju Model Konseptual Perkembangan Wilayah Pulau-Pulau Kecil di Indonesia. Majalah Geografi Indonesia. Yogyakarta. 
Stanford, R. J., Wiryawan, B., Bengen, D. G., Febriamansyah, R., \& Haluan, J. (2013). Exploring fisheries dependency and its relationship to poverty: A case study of West Sumatra, Indonesia. Ocean Coast Manag., 84, 140-152. http://dx.doi.org/10.1016/j.ocecoaman.2013.08.010

Tjondronegoro, Soejono, I., \& Hardjono, J. (1996). Poverty in Indonesia. In M. G. Quilibria (Ed.), Rural Poverty in Developing Asia. Part 2: Indonesia, Republic of Korea, Philipines and Thailand. Asian Development Bank, Manila.

\section{Copyrights}

Copyright for this article is retained by the author(s), with first publication rights granted to the journal.

This is an open-access article distributed under the terms and conditions of the Creative Commons Attribution license (http://creativecommons.org/licenses/by/4.0/). 